УДК 551.311.231:553.08

DOI: https://doi.org/10.17308/geology.2021.3/3650

Поступила в редакцию: 05.04.2020

Принята к публикации: 02.09.2021

Опубликована онлайн: 07.10.2021

\title{
Докембрийские источники алмазов россыпей фанерозоя
}

\author{
(C2021 Н. Н. Зинчук \\ Западно-Якутский научный центр (ЗЯНЦ) АН РС (Я) \\ Чернышевское шоссе, 16, 678170, Мирный, Российская федерация
}

\begin{abstract}
Аннотация
Введение: Проявления докембрийской продуктивности установлены для многих алмазоносных регионов мира. При этом количество известных коренных источников алмазов докембрийского возраста достаточно ограничено.

Методика: Результаты обобщения огромного фактического материала по комплексному изучению алмаза из верхнепалеозойских, мезозойских и современных осадочных толщ Сибирской платформы (СП) позволили получить новые данные по особенностям состава и распространению минерала в современных и древних отложениях основных алмазоносных районов Лено-Анабарской (ЛААСП), Центрально-Сибирской (ЦСАСП) и Тунгусской (ТАСП) субпровинций.

Результаты и обсуждение: На северо-востоке платформы оконтурен район Кютюнгинского грабена и прилегающих к нему территорий, перспективных на открытие богатых кимберлитовых тел со специфическими алмазами. Для ЦСАСП показано, что область развития отдельных макроассоциаций алмаза ограничивается конкретным алмазоносным районом, где развиты разновозрастные верхнепалеозойские и мезозойские отложения.

Заключение: Особенности алмазов из россыпей СП свидетельствуют о множественности первоисточников, а также наличии во многих алмазоносных районах ещё не открытых кимберлитовых тел. Важное значение имеет использование типоморфных особенностей кристаллов для восстановления экзогенной истории алмазов на пути от коренных источников до мест современного нахождения в россыпях. Это необходимо для палеогеографических реконструкций распространения древних продуктивных толщ и выяснения направлений сноса алмазоносного материала. Установленная в отдельных алмазоносных районах близость типоморфных особенностей алмазов в осадочных толщах свидетельствует о формировании вторичных коллекторов за счет размыва более древних (в том числе докембрийских) продуктивных толщ или среднепалеозойских коренных источников. Доказана полигенность минеральных ассоциаций алмазов из россыпей в пределах отдельных алмазоносных районов, что можно использовать при прогнозировании и поисках коренных источников минерала.

Ключевые слова: верхнепалеозойские и мезозойские отложения, Сибирская платформа, алмаз и алмазоносные россыпи.
\end{abstract}

Для цитирования: Зинчук Н. Н. Докембрийские источники алмазов россыпей фанерозоя // Вестник Воронежского государственного университета. Серия: Геология. 2021. №3. С. 50-59. DOI: https://doi.org/10.17308/geology.2021.3/3650

Контент доступен под лицензией Creative Commons Attribution 4.0 License.

\footnotetext{
Зинчук Николай Николаевич, e-mail: nnzinchuk@rambler.ru
} 
Проявления докембрийской продуктивности установлены для многих алмазоносных регионов мира [16]. При этом количество известных коренных источников алмазов докембрийского возраста достаточно ограничено. Это связано с рядом причин: перекрытием древних коренных источников более молодыми осадками; возможной большой величиной эрозионного среза. Из-за неё на уровне верхней эрозии тел могут обнажаться лишь незначительные по площади корневые части. Возможны также сильная измененность первичных пород, их необычный состав и т.д. Более широко представлены докембрийские россыпи алмазов [7-13]. Во многих случаях алмазы этих россыпей имеют высокое качество, благодаря чему такие алмазопроявления являются рентабельными даже при невысоком их содержании. Докембрийские алмазоносные формации Мира обоснованы по комплексу «признаков древности» алмазов, включающих:

a) своеобразный морфологический спектр алмазов, характеризующийся преобладанием округлых ромбододекаэдроидов, а также повышенное по сравнению с фанерозойскими источниками количество кубоидов;

б) наличие скрытокристаллических разновидностей алмаза - карбонадо и балласов, присущих только месторождениям докембрийского возраста;

в) зеленая окраска поверхностного слоя кристаллов и присутствие зеленых и бурых пятен пигментации, причиной появления которых является радиационное облучение алмазов в природных условиях и нагрев, изза чего зеленые пятна пигментации становятся коричневыми;

г) наличие алмазов, инкрустированных кварцем или заключенных в оболочку из мелкокристаллического кварца, претерпевших метаморфизм вмещающих пород;

д) значительный механический износ, выраженный в появлении выколков, серповидных и кольцевых трещин, ромбической сеточки трещин на поверхности кристаллов;

е) повышенная крупность и высокое качество алмазов как результат сортировки при формировании древних прибрежно-морских россыпей;

ж) ожелезнение кристаллов по поверхностным микротрещинам, вплоть до образования гематитовых оболочек и примазок окислов марганца, свидетельствующее о пребывании алмазов в условиях корообразования.

Комплекс «признаков древности» сыграл большую роль в двух отношениях: а) впервые была показана специфика докембрийской алмазоносности; б) представилась возможность выделять среди алмазов фанерозойских (в том числе современных) россыпей кристаллы, переотложенные из докембрийских россыпей. К числу важнейших признаков происхождения алмазов из докембрийских источников указано тяготение повышенных концентраций кристаллов с «признаками древности» к выступам докембрийского фундамента древних платформ. На Сибирской платформе (СП) это
Алданский и Анабарский щиты, Оленекское и Уджинское поднятия в Якутской алмазоносной провинции (ЯАП), а также Енисейский кряж. Исследованиями $[6,12]$ показана полезность данных критериев для выделения алмазов, потенциально связанных с докембрийскими источниками, хотя все они относятся к категории косвенных. По отдельности большинство из них свойственно и для алмазов из россыпей, сформированных за счет фанерозойских источников.

За последнее время существенно расширился феноменологический и концептуальный базис для оценки перспектив докембрийской алмазоносности. По результатам изучения россыпей северо-востока СП обосновано $[2,7,14]$ наличие в них групп алмазов (рис. 1), полностью отсутствующих в фанерозойских кимберлитах - V и VII разновидности по классификации Ю. Л. Орлова [15]. В этих кимберлитах в несопоставимо меньше, чем в россыпях II-ой разновидности алмазов, скрытоламинарных округлых ромбододекаэдров бразильского или уральского типов. Кроме того, необычно изотопически легкий состав углерода алмазов V и VII разновидностей, преобладание алмазов эклогитовых парагенезисов, высокая степень механического износа, недостижимая в фанерозойских условиях россыпеобразования позволили предполагать $[2,7]$ происхождение алмазов из докембрийских источников двух типов. Это кимберлиты или лампроиты, из которых могут поступать округлые ромбододекаэдроиды, и неизвестные породы, из которых транспортировались алмазы V, VII и II разновидностей [15]. Алмазы V и VII разновидностей распространены только в россыпях северовостока СП, что дает основание предполагать эндемичность их источников.

Bce потенциально докембрийские алмазы могли пройти через протерозойские прибрежно-морские россыпи. Впоследствии более поздние физико-химические изменения обусловили полное уничтожение минералов-индикаторов (ИМК) коренных источников алмазов. Достоверно не выделены минералы - парагенетические или парастерические спутники этих алмазов, а кимберлитовые минералы (гранаты, пикроильмениты и хромшпинелиды) происходят из молодых кимберлитов и являются лишь гидравлическими попутчиками потенциально докембрийских алмазов $[2,10-12,16]$. Несмотря на гипотетический характер, указанные предпосылки докембрийской алмазоносности весьма эвристичны. Они позволяют непротиворечиво соединить данные по алмазоносности СП, не находящие объяснения в концепции исключительно фанерозойской и только кимберлитовой алмазоносности и расширить представления о структурнотектонической позиции россыпей и россыпепроявлений потенциально докембрийских алмазов.

Распределение алмазов из предполагаемых типов докембрийских коренных источников СП различается весьма значительно. Алмазы V и VII разновидностей распространены только в россыпях северо-востока платформы, причем их суммарное количество может 
достигать $[2,7,17]$ половины продукции россыпи (россыпи реки Эбелях). Однако на более южных участках их доля быстро уменьшается и южнее реки Муна алмазы этих разновидностей практически не встречаются. Не обнаружены они и на западном - юго-западном обрамлении Анабарского щита, на территории Красноярского края, на юге платформы в Иркутской области (рис. 2). В литературе имеются описания алмазов $\mathrm{V}$ разновидности из различных районов и источников [6], однако, эти кристаллы диагностированы только по физиографическим признакам [3] и по комплексу типоморфных особенностей (изотопный состав углерода, структура, физические особенности) отличаются от аналогичной группы алмазов из россыпей северо-востока СП [9]. Считается, что распространенные на северо-востоке платформы алмазы V и VII разновидностей принадлежат к одному генетическому типу и являются эндемичными [7].

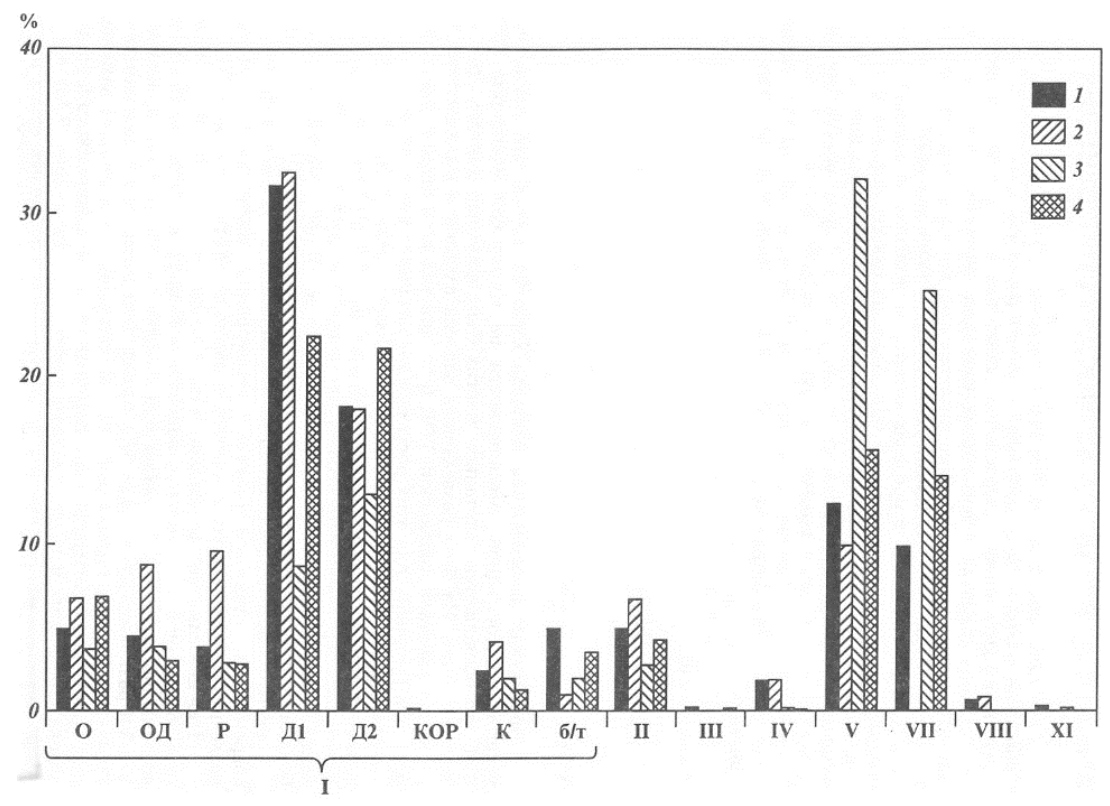

Рис. 1. Типоморфные особенности алмазов из современных россыпей Анабарского алмазоносного района. Условные обозначения: $I-V, V I I, V I I I, X I-$ разновидности алмазов по Ю. Л. Орлову (О - октаэдры, ОД - переходные формы, $P$ - ламинарные ромбододекаэдры, Д1 - додекаэдры скрытослоистые, Д2 - додекаэдры с шагренью, $K O P$ - куборомбододекаэдры, $K$-кубы, $\sigma / m$ осколки). 1-4 - поля: 1 - Майат-Уджинское, 2 - Куонапское, 3 - Нижнеэбеляхское (участок Ырас-Юрэх), 4 - Верхнеэбеляхское (участок Исток).

[Fig. 1. Typomorphic features of diamonds from modern placers of the Anabar diamond-bearing region: $I$-V, VII, VIII, XI - varieties of diamonds according to Yu. L. Orlov $(O$ - octahedrons, $O D$ - transitional forms, $P$ - laminar rhombododecahedrons, $D 1-$ crypto-layered dodecahedrons, $D 2$ - dodecahedrons with shagreen, KOR - cubic dodecahedrons, $K$ - cubes, b/t - fragments). (1-4) - fields: (1) - MayatUdzhinskoe, (2) - Kuonapskoe, (3) - Nizhneebelyakhskoe (Yras-Yurekh section), (4) - Verkhneebelyakhskoe (Istok section).]

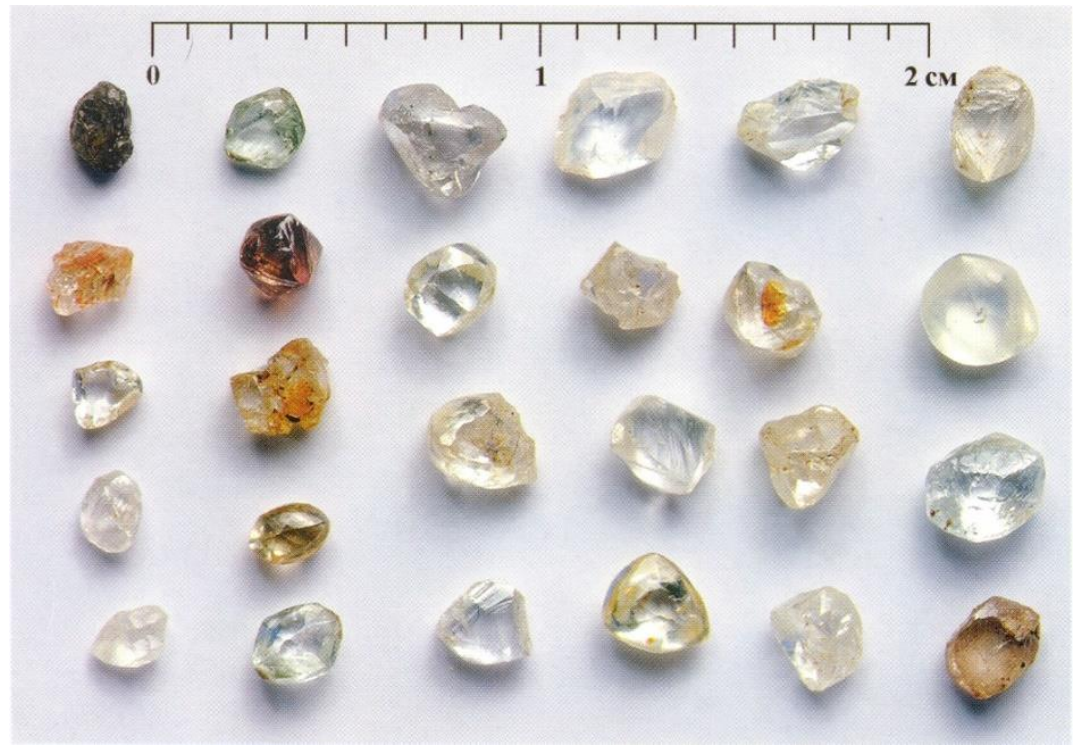

Рис. 2. Фото алмазов из современных отложений р. Нижняя Тунгусска.

[Fig. 2 Photo of diamonds from modern sediments of the Nizhnyaya Tunguska River.] 
Более распространенные алмазы II разновидности в незначительных количествах обнаружены в россыпях и в фанерозойских кимберлитах в разных частях платформы, однако, максимальные концентрации их (до $50 \%$ от общего количества) также характерны для северо-восточной части СП, где они тяготеют к выступам докембрия. Наиболее широко распространены округлые ромбододекаэдроиды I разновидности [6]. В переменных количествах они встречаются в россыпях по всей территории СП, тяготея к выступам докембрия [2] Практически всегда округлые алмазы имеют повышенный размер (крупнее 1 мм), что связано [10-12] с гидравлической сортировкой при формировании протерозойских прибрежно-морских коллекторов, из которых они переотлагались в более молодые отложения. Если в россыпях преобладают мелкие кристаллы (менее 1 мм), шансы встретить среди них округлые потенциально докембрийские алмазы невелики. Так, в россыпи реки Тычана (Тычанский алмазоносный район, Красноярский край) характеризующейся повышенной крупностью минералов, округлые потенциально докембрийские алмазы составляют 30-40\%, тогда как в россыпи Тарыдакская того же района, содержащей мелкие образования, таких кристаллов не встречено [6]. Не установлены такие кристаллы и в россыпи Дьукунахская в верховьях реки Аламджа (приток реки Вилюй).

Все эти россыпи формировались в прибрежно-морских условиях [2] и имеют хорошую гидравлическую сортировку ИМК, которая и обеспечила накопление потенциально докембрийских алмазов вместе с фанерозойскими кимберлитовыми кристаллами в россыпях с крупными гранулометрическими классами и отсутствие на перспективных участках с мелкими зернами минерала. Можно констатировать, что округлые потенциально докембрийские алмазы распространены в качестве минерального фона по всей СП. Такие алмазы содержатся [9] в лампроитовых жилах Ингашинского поля в Восточном Саяне, имеющих протерозойский возраст (1268 \pm 12 млн лет). Округлые алмазы распространены в мире повсеместно. Часто они достоверно связаны [2, 7] с докембрийскими коренными источниками и россыпями (трубка Маджгаван и россыпи PR в Индии; дайковый кимберлитовый комплекс с возрастом 1200-400 млн лет и россыпепроявления в докембрийских формациях Тортья, Лекор, Бирим в Западной Африке; алмазоносные филлиты и докембрийские россыпи в Бразилии).

Различия в распределении алмазов указанных групп на СП подчеркиваются коэффициентами корреляции, характеризующими их связь в россыпях между собой. Коэффициент корреляции распределения V и VII разновидностей составляет +0.67 , что дополнительно свидетельствует [6-7] об их генетическом родстве и происхождении из общего источника (источников). Коэффициент корреляции между $\mathrm{V}+\mathrm{VII}$ и II разновидностями составляет +0.05 , т.е. эти группы полностью независимы и происходят из разных источников. Коэффициент корреляции между V+VII разновидностями и округлыми алмазами составляет -0.55 . Высокая отрицательная корреляция отражает локальность распределения V+VII групп на фоне повсеместного по СП нахождении округлых алмазов: по мере снижения доли первых растет доля округлых алмазов, что свидетельствует о независимости источников последних. Из этого следует, что все три указанные группы алмазов имеют свои типы коренных источников (наиболее вероятно докембрийского возраста) и различаются по характеру распределения.

Тяготение максимумов распределения алмазов V, VII и II разновидностей к выступам докембрия на северо-востоке СП достаточно очевидно. Вместе с ними здесь присутствуют округлые ромбододекаэдроиды, распространенные и в Красноярском крае (Тычанский район), где их появление можно связать с размывом протерозойских отложений на Енисейском кряже. Алмазы Иркутской области (рис. 3), представлены в основном ромбододекаэдроидами [6,7]. Они связаны с размывом выступов докембрия в Восточном Саяне, где располагаются также пока единственные известные на платформе докембрийские алмазоносные лампроиты Ингашинского поля [10].

Менее известны алмазы в отложениях Алданского щита. Там в начале 50-х годов прошлого столетия были найдены [2, 3] два алмаза в устье ручья Трудовой (приток реки Джеконда) при обогащении 14000 м $^{3}$ образований золотой россыпи и целика аллювия. Тем не менее, имеются реальные свидетельства потенциальной алмазоносности этой структуры. При этом ИМК на территории щита не обнаружены, а изучение многочисленных трубочных и дайковых тел основного и ультраосновного состава мезозойского возраста на данной территории не выявило их алмазоносности. Предполагается [2, 7], что находки алмазов на территории Алданского щита связаны с докембрийскими коренными источниками (типа кимберлитов или лампроитов), алмазы которых попадают в современный аллювий через протерозойские (вендские) прибрежно-морские коллекторы.

Более сложно интерпретировать появление повышенной доли округлых ромбододекаэдроидов в тех случаях, когда выступы докембрия не картируются на дневной поверхности. Так, к районам, для которых характерно повышенное количество округлых ромбододекаэдроидов, относится Приленский район СП [5, 7]. В небольших количествах на этой территории встречены (до 10\%) алмазы V, VII и кристаллы II (до 11\%) разновидностей. Доля округлых алмазов здесь повышается до 70\% и наиболее характерны они для россыпей Среднего Молодо и Моторчуны ЯАП, где они имеют «признаки древности», заключающиеся, помимо габитуса, в форме повышенного механического износа, зеленой пигментации, матировки, связанной с термическим воздействием, повышенной крупности и высокого качества $[7,12]$. Выступов докембрия, с которыми можно было бы связать данные алмазы, здесь не закартировано. Однако имеются сведения [10], что к началу накопления образований мезозоя, в течение 


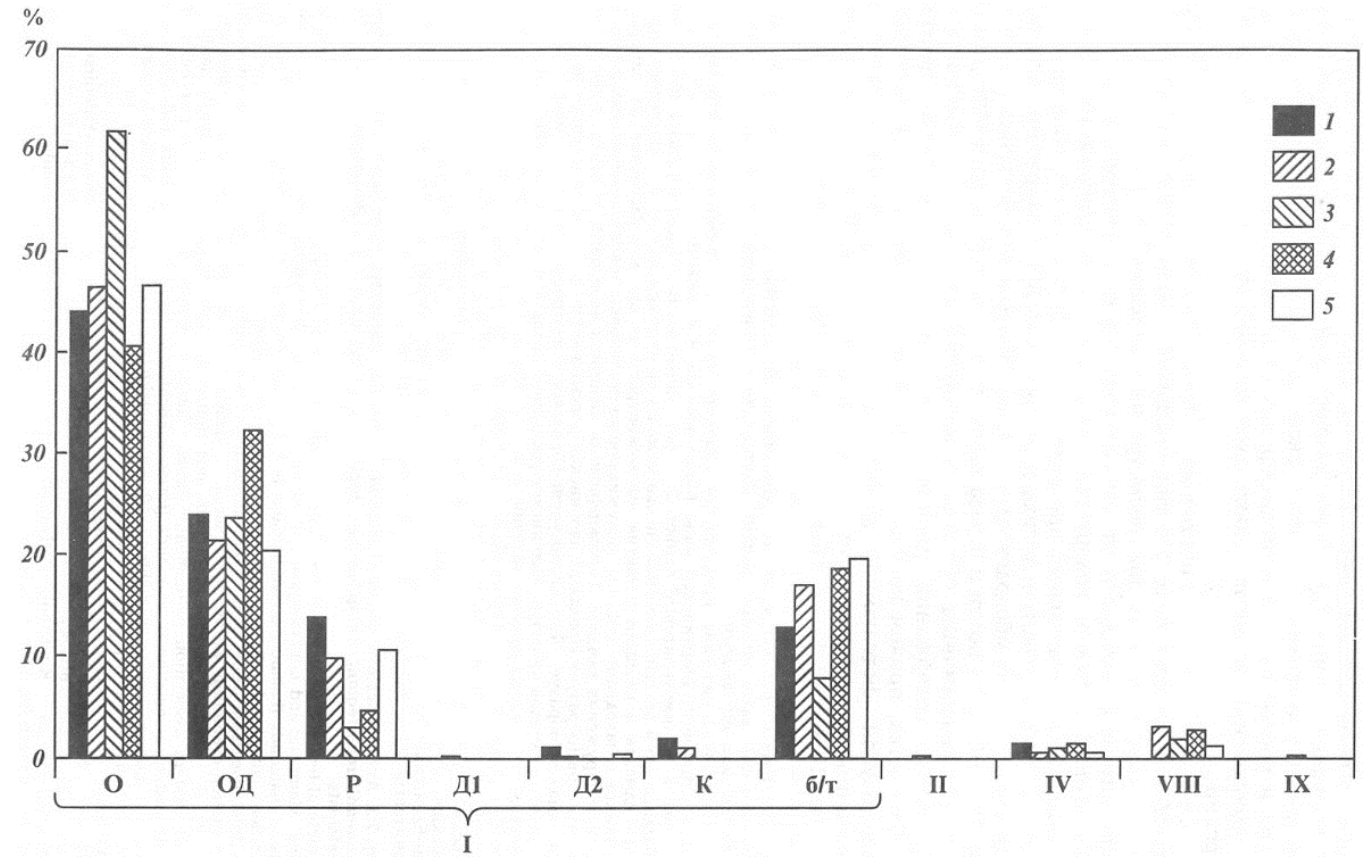

Рис. 3. Типоморфные особенности алмазов из россыпей МБАР. Условные обозначения: I, ПI, IV, VIII, IX - разновидности алмазов по Ю. Л. Орлову ( $O$ - октаэдры, $O Д$ - переходные формы, $P$ - ламинарные ромбододекаэдры, Д1 - додекаэдры скрытослоистые, Д2 - додекаэдры с шагренью, $K$ - кубы, $\sigma / m$ - осколки). $1-5$ - участки: 1 - Улахан-Еленгский, 2 - Глубокий, 3 - Солур, 4 - Куранахский, 5 - Таборный.

[Fig. 3. Typomorphic features of diamonds from Malobotuobinsky diamond-bearing region placers: $I-V, I V$, VIII, IX-varieties of diamonds according to Yu. L. Orlov $(O$ - octahedrons, $O D$ - transitional forms, $P$ - laminar rhombododecahedrons, $D 1-$ crypto-layered dodecahedrons, $D 2$ - dodecahedrons with shagreen, KOR - cubic dodecahedrons, $K$ - cubes, $b / t$ - fragments). (1-5) - sections: (1) - UlakhanYelengsky, (2) - Gluboky, (3) - Solur, (4) - Kuranakhsky, (5) - Taborny.]

которого сформировался современный структурный план территории, граница платформы пролегала восточнее современной. На месте Ленского отрезка Приверхоянского краевого прогиба располагался крупный выступ докембрийского фундамента, долгое время служивший областью сноса терригенного материала (в том числе алмазов) на запад в сторону платформы и на восток в Верхоянскую геосинклиналь [5].

Повышенная доля округлых алмазов обнаруживается в некоторых россыпях центральной части ЯАП. Так, их доля в аллювии реки Вилюй выше устья реки Малая Ботуобия составляет 20.4\%. Алмазы здесь были обнаружены в 50-е годы прошлого века при использовании больших объемов опробования (аналогично Алданскому району). Ниже устья реки Малая Ботуобия концентрация алмазов в аллювии резко возрастает, а их морфологический спектр соответствует (см. рис. 3) кимберлитам Малоботуобинского алмазоносного района (МБАР). Алмазы реки Вилюй выше устья Малой Ботуобии представляют собой фон, который можно обнаружить лишь большими объемами опробования, тогда как ниже устья этой реки характер ассоциации алмазов полностью определяется кимберлитами Мирнинского кимберлитового поля (МКП). Алмазы преимущественно октаэдрического габитуса; фоновые округлые их разности имеются и здесь, но играют незначительную роль по сравнению с кристаллами из местных кимберлитов. Промышленные кимберлиты МКП, в значительной мере определяющие россыпную алмазоносность региона, не могли служить источни- ком округлых алмазов. Однако не исключена связь последних с Сунтарским выступом докембрийских пород, в настоящее время перекрытых мезозойскими отложениями незначительной мощности. Поэтому, помимо выступов докембрия, экспонированных в настоящее время на дневной поверхности, необходимо учитывать и аналогичные структуры, перекрытые мезозойскими или верхнепалеозойскими отложениями, поскольку они могли служить источниками докембрийских алмазов, впоследствии неоднократно переотлагавшихся во все более молодые осадки. Практически со всеми выступами фундамента связаны потенциально докембрийские алмазы, что позволяет предполагать распространенность таких кристаллов под палеозойским осадочным чехлом.

Кроме древних платформ, где находки алмазов не вызывают сомнения, минерал встречается в складчатых областях. Чаще всего эти находки принадлежат не специалистам в области изучения алмазов, и во многих случаях вызывают сомнения, поскольку минерал остается не изученным должным образом. Удалось детально изучить алмаз, найденный при добыче золота в Аллах-Юньской золотоносной россыпи [2], который извлечен при ручной разборке концентрата фракции $>4$ мм, полученного при промывке аллювия. По поверхности алмаза развиты мелкие зеленые пятна пигментации с размытыми контурами. Из наблюдаемых кристалло-морфологических особенностей наиболее важное значение для установления происхождения этого алмаза в россыпи имеют следующие $[7,10]$ : 
а) повышенная степень механического износа; износ такой степени характерен для алмазов из прибрежно-морских россыпей и не мог осуществиться в аллювиальных условиях; это дает основания полагать, что в современную аллювиальную золотоносную россыпь он попал из более древнего коллектора;

б) ромбическая сеточка трещин - «признак древности» и встречается на алмазах из докембрийских или потенциально докембрийских россыпей северо-востока СП, Урала, Китая, Индии, Бразилии и других регионов; возникновение трещинок вызвано хрупкой релаксацией поверхностных напряжений, обусловленных соударениями с твердыми частицами в процессе формирования древней россыпи, под действием более поздних физико-химических факторов;

в) пятна пигментации, входящие в комплекс «признаков древности» наиболее характерны для алмазов из докембрийских россыпей.

Каждый из указанных морфологических признаков сам по себе может встречаться на алмазах из россыпей разного возраста. Однако в комплексе они с высокой степенью вероятности свидетельствуют о докембрийском возрасте россыпей. Поэтому можно предполагать $[2,7]$ происхождение данного алмаза из докембрийской алмазоносной прибрежно-морской россыпи.

Имеются сведения [10] о находке в верховьях реки Мома (правый приток реки Индигирка) «алмазной породы». Данный район представляет собой мезозойское складчатое обрамление Колымского платформенного блока. Наиболее вероятно такая порода представляет собой осадочный алмазоносный коллектор, который может иметь как докембрийский (протерозойский) возраст, так и более молодой, если алмазы были переотложены из древнего осадочного коллектора. Подобная ситуация известна [2, 6] в Китае в провинции Хунань, где алмазы найдены в середине XIX века в русловых отложениях реки Юаньцзян, а в настоящее время здесь эксплуатируется россыпное месторождение Чандэ. Изучено 112 алмазов из аллювиальных отложений бассейна этой реки $[2,10]$. Китайские геологи делят алмазоносные участки на «ореолы» (где алмазы встречаются в сопровождении ИМК - пиропов и хромитов) и «россыпи» (где алмазы не сопровождаются кимберлитовыми или лампроитовыми минералами, а их основным гидравлическим спутником является диаспор из пермской латеритной коры выветривания). И в ореолах, и в россыпях уверенно выделяются алмазы с «признаками древности», выраженными в габитусе (округлые додекаэдроиды и октаэдроиды), механическом износе, разнообразных следах удара в форме ромбической сеточки трещин, кольцевых и серпообразных трещинок поперек псевдоребер додекаэдроидов и октаэдроидов, многие кристаллы имеют радиационную окраску (сплошную зеленоватую либо пятнистую пигментацию). В «ореолах» к ним добавляются (преимущественно в мелких гранулометрических классах) кристаллы октаэдрического габитуса, не обладающие характерными «признаками древности» и связанные, возможно, с фанерозойскими источниками (здесь известны 25 жильных и трубочных тел лампроитов среднепалеозойского возраста, однако алмазоносных тел пока не найдено).

Россыпи алмазов обнаружены $[2,10]$ в последние годы в Мьянме (Бирма) в пределах мезозойской Бирмано-Малайской складчатой системы. Среди алмазов резко преобладают округлые ромбододекаэдроиды, средний вес кристаллов около 0.3 карата, но есть и крупные; более чем 50\% кристаллов имеют на поверхности зеленые и бурые пятна пигментации и характеризуются механическим износом. В районе находок алмазов обнажается широкий возрастной спектр пород, начиная с архейских. Сделано предположение [2] о магматическом первоисточнике алмазов (скорее лампроитовом, чем кимберлитовом), но отмечается также, что кристаллы попали в современные отложения через промежуточный коллектор. Возраст промежуточного коллектора не уточняется, а отмечается лишь длительная аллювиальная история алмазов. Однако по описаниям алмазов и фотографиям видно [10], что они в максимальной степени соответствуют «признакам древности» и в соответствии с развиваемой нами [2] концепцией происходят из докембрийской прибрежно-морской россыпи, возраст коренных источников которой также докембрийский. Поддерживая имеющуюся точку зрения о лампроитовом характере этих источников, можно ссылаться как на миоценовые лампроиты поля Эллендейл в Австралии, так и на кимберлит-лампроитовую трубку Маджгаван в Индии, алмазы которой очень похожи на аналогичные кристаллы Мьянмы [1820]. Вероятно, такая ситуация имеет место [7] на острове Калимантан (Борнео). Здесь развита мезозойская складчатость, характерная для всей юго-восточной Азии. В западной и юго-западной частях острова уже несколько веков известны аллювиальные россыпи алмазов, коренные источники которых не установлены. Среди алмазов доминируют октаэдры (вероятно, октаэдроиды) и ромбододекаэдры (округлые ромбододекаэдроиды). Значительная часть из них (особенно в западной части острова) имеет признаки механического износа. Вес алмазов преимущественно до 0.33 карата, однако известны и крупные алмазы, например «Звезда Серавака» весом 87 каратов, найденный в 1877 г., а также еще один кристалл весом 70 каратов [7, 10]. Главным гидравлическим спутником алмазов является диаспор и корунд, а также корундо-диаспоровые породы «леборштейны». Для суждения об источниках алмазов важны два обстоятельства: а) механический износ алмазов; б) характер гидравлических спутников. По поводу первого можно утверждать, что в аллювиальных условиях небольших рек, развитых на острове, износ алмазов не отмечен. Алмазы попадали в современный русловой аллювий при дренировании более древних коллекторов, которыми могут быть позднемеловые конгломераты с редкими алмазами.

Аналогичным образом можно анализировать алмазоносность других зон на различных континентах, в частности мезозойской складчатости острова Суматра, запада Соединенных Штатов Америки (Калифорния, 
Орегон), а также горной системы Аппалачей [7]. Алмазы Урала также являются [2], докембрийскими, поскольку по данным других исследователей $[5,11]$ они имеют типичные «признаки древности» и весьма похожи на кристаллы из россыпей PR района Панна или Вайджаракарур (Индия). Так называемые «туффизиты» Урала, объявленные коренными источниками алмазов, не могут быть таковыми хотя бы потому, что их кристаллы имеют признаки механического износа в форме «леденцовых поверхностей», являющихся результатом механической полировки алмазов в процессе формирования древних россыпей.

Перечисленных примеров достаточно для того, чтобы показать высокую реальность появления алмазов с «признаками древности» в складчатых областях за счет размыва древних промежуточных коллекторов. Разумеется, россыпная гипотеза не может рассматриваться безальтернативно. Алмазы могут поступать и из коренных источников разного возраста (как фанерозойских, так и докембрийских), как лампроиты Ингашинского поля в Восточном Саяне. Однако знание минералогии алмазов и их экзогенных изменений позволяет даже по единичным кристаллам во многих случаях сделать выбор [7] в рамках альтернативы «коренной источник - древняя россыпь». К сожалению, данная альтернатива во многих случаях даже не рассматривается. Так, имеются сведения о находках крупных алмазов ювелирного качества (два потенциальных «признака древности») на территории Казахстана, а также в горах Тянь-Шаня. По проблеме алмазоносности Казахстана в основном рассматриваются только гипотезы относительно возможных коренных источников алмазов.

Наряду с известным месторождением метаморфогенных алмазов Кумдыколь (Кокчетавский массив) в качестве источников предполагаются пермские базальты, разнообразные магматиты, содержащие ксенолиты предположительно алмазоносных мантийных пород, блоки «алмазного слоя» мантии, выброшенные на поверхность в связи с формированием гигантских астроблем - гиаблемы, докембрийские полиметаморфиты, кимберлиты и лампроиты без указания возраста. Некоторые из этих источников вероятно, действительно алмазоносны, в частности нижнетриасовые субщелочные оливиновые базальты Кастекского хребта, однако их алмазы мелкие (0.02-0.2 мм) с разнообразной морфологией, желтого и желтовато-зеленого цвета. Реальным источником ювелирных алмазов могут быть древние осадочные коллекторы [7], дренируемые в горах. Их алмазы могут иметь разный генезис (наиболее вероятно кимберлитовый или лампроитовый), но в данном случае важен не только тип коренного источника, а и особенности поисковой обстановки, определяющие геологическую позицию этих кристаллов, возможности и ограничения поисков их коренных источников. При этом сами алмазы могут ответить $[2,7]$ на вопрос, из коренного источника или из древней россыпи они появились на дневной поверхности. К сожалению, нередко кроме факта находок не приводится никакой информации (особенно геологической) об этих алмазах. Поэтому изначально при прогнозировании необходимо предполагать два варианта алмазоносности - «коренной» и «россыпной» и находки алмазов анализировать с обеих позиций, что поможет избежать многих заблуждений.

\section{Заключение}

Проведенные исследования и анализ опубликованного по данной проблеме материала позволяют утверждать, что алмазы в россыпях из докембрийских источников могут занимать различную геологическую позицию: а) находиться в докембрийских отложениях, как на древних платформах, так и в более молодых складчатых системах, сформированных на древнем платформенном основании; б) присутствовать в фанерозойских и современных россыпях, сформированных за счет размыва докембрийских пород в пределах выступов докембрия на платформах; в) находиться в современных россыпях, сформированных за счет размыва выходов докембрийских коллекторов в фанерозойских складчатых системах, сформированных на древнем платформенном основании; г) появляться в фанерозойских отложениях как результат переотложения из докембрийских коллекторов; д) встречаться либо самостоятельно, сопровождаясь лишь гидравлическими спутниками, либо в сопровождении алмазов и других ИМК из фанерозойских кимберлитов. Поэтому находки алмазов в древних и современных россыпях необходимо рассматривать с двух позиций: попадание их в россыпи либо за счет размыва непосредственно коренных источников, либо за счет размыва осадочных коллекторов (в том числе докембрийских). Идентификация алмазов в данной альтернативе осуществляется по комплексу типоморфных особенностей, связанных с экзогенными изменениями алмазов, при этом докембрийские алмазы характеризуются комплексом «признаков древности». Во втором случае поисковая обстановка может накладывать серьезные ограничения на возможность прогнозирования и поисков коренных месторождений, одновременно давая возможность прогнозировать россыпную алмазоносность, связанную с докембрийскими источниками.

Очень важно обращать внимание на психологический аспект проблемы прогноза алмазоносности на территориях возможного присутствия докембрийских алмазов. Обычно при находке алмазов в россыпях в первую очередь выдвигаются гипотезы о коренных источниках, их структурно-тектонической позиции исходя из аналогий с известными типами коренных источников, при этом в качестве потенциальных источников алмазов рассматриваются главным образом кимберлиты (лампроиты), ультрабазиты (реже базиты), однако обычно возраст источников специально не обсуждается. Происхождение алмазов из древних россыпей рассматривается как второстепенный вариант, а возможность поступления кристаллов из докембрийских источников практически не принимается во внимание. Такая ситуация характерна для прогноза алмазо- 
носности как по СП, так и по другим платформам Мира, хотя там известны находки докембрийских алмазоносных лампроитов.

Без анализа возможной докембрийской алмазоносности можно долго и бесплодно решать проблему источников алмазов на северо-востоке СП, искать фанерозойские источники россыпей реки Юаньцзян и т.д. В то же время с позиций докембрийской алмазоносности можно прогнозировать россыпи алмазов в районах выходов докембрия, как это проделано для плато Контум во Вьетнаме. Есть основание предполагать наличие докембрийских алмазов (наряду с кристаллами из фанерозойских кимберлитов) в провинциях Ляонин и Шаньдун (Китай), поскольку на их территории имеются выходы докембрия, и не все проявления россыпной алмазоносности можно объяснить наличием известных в данном регионе кимберлитов. Алмазы установлены как в современных аллювиальных, так в синийских и кембрийских отложениях. Приведенные материалы позволяют утверждать о широком развитии докембрийской алмазоносности на Земле. Этот факт необходимо учитывать при идентификации тех или иных находок алмазов в россыпях и алмазопроявлениях различных регионов.

Конфликт интересов: Автор декларирует отсутствие явных и потенциальных конфликтов интересов, связанных с публикацией настоящей статьи.

\section{ЛИТЕРАТУРА}

1. Афанасьев В. П., Елисеев А. П., Надолинный В. А., Зинчук Н. Н., Коптиль В. И., Рылов Г. М., Томиленко А. А., Горяйнов С. В., Юрьева О. Л., Сонин В. М., Чепуров А. И. Минералогия и некоторые вопросы генезиса алмазов V и VII разновидности (по классификации Ю. Л. Орлова) // Вестник Воронежского государственного университета. Серия: Геология. 2000. №5 (10). С. 79-96.

2. Афанасьев В. П., Зинчук Н. Н. Минералогия древних россыпей алмазов восточного борта Тунгусской синеклизы // Геология и геофизика. 1987. №1. С.90-96.

3. Зинчук Н. Н., Савко А. Д., Крайнов А. В. Кимберлиты в истории Земли. Труды научно-исследовательского института геологии: Воронеж, Изд-во Воронеж. гос. ун-та. Вып. 68, 2013. $99 \mathrm{c}$.

4. Афанасьев В. П., Зинчук Н. Н., Коптиль В. И. Полигенез алмазов в связи с проблемой коренных россыпей северо-востока Сибирской платформы // Доклады Академии наук. 1998. Т.361. №3. С. 366-369.

5. Зинчук Н. Н. Сравнительная характеристика вещественного состава коры выветривания кимберлитовых пород Сибирской и Восточно-Европейской платформ // Геология $u$ геофизика. 1992. №-7. С. 99-109.

6. Афанасьев В. П., Зинчук Н. Н., Тычков С. А. Проблема алмазоносности Сибирской платформы // Вестник Воронежского государственного университета. Серия: Геология. 2002. №1. C. 19-36.

7. Савко А. Д., Зинчук Н. Н., Шевырёв Л. Т., Ильяш В. В.,
Афанасьев Н. С. Алмазоносность Воронежской антеклизы. Труды научно-исследовательского института геологии: Воронеж, Изд-во Воронеж. гос. ун-та. 2003. Вып.17, 121 с.

8. Афанасьев В. П., Зинчук Н. Н. Основные литодинамические типы ореолов индикаторных минералов кимберлитов и обстановки их формирования // Геология рудных месторождений. 1999. Т. 41. №3. С. 281-288.

9. Зинчук Н. Н., Коптиль В. И., Борис Е. И., Липашова А. Н. Типоморфизм алмазов из россыпей Сибирской платформы как основа поисков алмазных месторождений // Pуды и металльь. 1999. №3. С. 18-30.

10. Зинчук Н. Н., Савко А. Д., Коптиль В. И., Чашка А. И., Полканов Ю. А., Палкина Е. Ю., Хренов А. Я., Шевырев Л. Т. Сравнительная характеристика типоморфных особенностей алмазов из терригенных отложений Воронежской антеклизы (Липецкая область) и Украинского щита (Среднее Приднестровье) в связи с проблемой прогнозирования и поисков их коренных источников // Вестник Воронежского государственного университета. Серия: Геология. 2004. №2. C. $99-110$.

11. Мальцев М. В., Толстов А. В., Фомин В. М., Старкова Т. С. Новое кимберлитовое поле в Якутии и типоморфные особенности его минералов-индикаторов // Вестник Воронежского государственного университета. Серия: Геология. 2016. №3. C. 86-94.

12. Василенко В. Б., Зинчук Н. Н., Кузнецова Л. Г. Геодинамический контроль размещения кимберлитовых полей центральной и северной частей Якутской кимберлитовой провинции (петрохимический аспект) // Вестник Воронежского государственного университета. Серия: Геология. 2000. №3.(9). С. 37-55.

13. Метелкина М. П., Прокопчук Б. И., Суходольская О. В., Францессон Е. В. Докембрийские алмазоносные формации Мира. М.: Недра. 1976. 134 с.

14. Зинчук Н. Н., Борис Е. И., Яныгин Ю. Б. Особенности минерагении алмаза в древних осадочных толщах (на примере верхнепалеозойских отложений Сибирской платформы). М.: МГТ. 2004. $172 \mathrm{c.}$

15. Орлов Ю. Л. Минералогия алмаза. 2-е изд. М.: Наука. 1984. $264 \mathrm{c}$.

16. Афанасьев В. П., Похиленко Н. П., Логвинова А. М., Зинчук Н. Н., Ефимова Э. С., Сафьянников В. И., Красавчиков В. О., Подгорных М. М., Пругов В. П. Особенности морфологии и состава некоторых хромшпинелидов алмазоносных площадей в связи с проблемой «ложных» индикаторов кимберлитов // Геология и геофизика. 2000. Т.41. №12. С.1729-1741.

17. Зинчук Н. Н., Мельник Ю. М., Серенко В. П. Апокимберлитовые породы // Геология и геофизика. 1987. №10. С. 6672.

18. Зинчук Н. Н., Зуев В. М., Коптиль В. И., Чёрный С. Д. Стратегия ведения и результаты алмазопоисковых работ // Горный вестник. 1997. №3. С. 53-57.

19. Афанасьев В. П., Зинчук Н. Н., Логвинова А. Н. Особенности распределения россыпных алмазов, связанных с докембрийскими источниками // Записки Российского минералогического общества. 2009. Т.138. №2. С. 1-13.

20. Grachanov S. A., Zinchuk N. N., Sobolev N. V. The age of Predictable primary diamond sources in the Northeastern Sibirian platform // Doklady Earth Sciences. 2015. Vol. 465. №2. P.12971301. 


\title{
Precambrian sources of diamonds in Phanerozoic placers
}

\author{
(C2021 N. N. Zinchuk ${ }^{\bowtie}$ \\ West-Yakutian Scientific Centre of the SR (Yakutia) Academy of Sciences, \\ Tchernischewski sch.,16, 678170, Mirni, Russian Federation
}

\begin{abstract}
Introduction: Manifestations of Precambrian producibility were identified for many diamond-bearing regions in the world. However, the number of known Precambrian primary sources of diamonds is rather limited.

Methodology: The results of a summary of the great amount of factual data from complex studies of diamonds from the Upper Paleozoic, Mesozoic, and recent sedimentary strata of the Siberian platform (SP) allowed obtaining new data on the specific features of the composition and distribution of the mineral in recent and ancient deposits of the main diamond-bearing regions of the Leno-Anabar, Central Siberian, and Tunguska sub-provinces.

Results and discussion: The area of the Kyutyunginsky graben and the neighbouring territories that can be promising for the discovery of kimberlite bodies with specific diamonds was outlined in the north-east of the platform. It was shown for the Central Siberian sub-province that the region of the development of individual macroassociations of diamonds is limited by a certain diamond-bearing region where Upper Paleozoic and Mesozoic deposits of different ages are represented.

Conclusions: The specific features of the diamonds from the SP placers indicate that there are multiple primary sources and there are yet undiscovered kimberlite bodies in many diamond-bearing regions. The use of typomorphic features of crystals is important for the reconstruction of the exogenous history of diamonds on their path from primary sources to their modern presence in placers. It is essential for paleogeographic reconstructions of the distribution of ancient productive strata and for the determination of the source areas of diamond-bearing materials. The similarity of typomorphic features of diamonds in sedimentary strata established in certain diamond-bearing regions indicates the formation of secondary reservoirs due to the drainage of more ancient productive strata (including Precambrian ones) or Middle Paleozoic primary sources. We confirmed the polygenetic nature of mineral associations of diamonds from placers within certain diamond-bearing regions, which can be used for the prediction of and search for the primary sources of the mineral.
\end{abstract}

Key words: Upper Paleozoic and Mesozoic sediments, Siberian platform, diamond and diamond-bearing placers.

For citation: Zinchuk N. N. Precambrian sources of diamonds in Phanerozoic placers. Vestnik Voronezhskogo gosudarstvennogo universiteta. Seriya: Geologiya - Proceedings of Voronezh State University. Series: Geology, 2021, no. 3, pp. 50-59. DOI: https://doi.org/10.17308/geology.2021.3/3650

Conflict of interests: The authors declare the absence of obvious and potential conflicts of interest related to the publication of this article.

The content is available under Creative Commons Attribution 4.0 License.

\footnotetext{
${ }^{凶}$ Nikolay N. Zinchuk, e-mail: nnzinchuk@rambler.ru
} 


\section{REFERENCES}

1. Afanas'ev V. P., Eliseev A. P., Nadolinnyi V. A., Zinchuk N. N., Koptil' V. I., Rylov G. M., Tomilenko A. A., Goryainov S. V., Yur'eva O. L., Sonin V. M., Chepurov A. I. Mineralogiya i nekotorye voprosy genezisa almazov V i VII raznovidnosti (po klassifikatsii Yu.L. Orlova) [Mineralogy and some questions of the genesis of diamonds of V and VII varieties (according to the classification of YL Orlov)]. Vestnik Voronezhskogo gosudarstvennogo universiteta. Seriya: Geologiya - Proceedings of Voronezh State University. Series: Geology, 2000, no. 5 (10), pp. 79-96. (In Russ.)

2. Afanas'ev V. P., Zinchuk N. N. Mineralogiya drevnikh rossypei almazov vostochnogo borta Tungusskoi sineklizy [Mineralogy of ancient diamond placers of the eastern side of the Tunguska syneclise] Geologiya i geofizika - Geology and geophysics, 1987, no. 1, pp. 90 96. (In Russ.)

3. Zinchuk N. N., Savko A. D., Krainov A. V. Kimberlity v istorii Zemli [Kimberlites in the history of the Earth.]. Trudy Nauchno-issledovatel'skogo Instituta Geologii [The work of the Research Institute of Geology], Voronezh, VSU Publ., vol. 68, 2013, 99 p. (In Russ.)

4. Afanas'ev V. P., Zinchuk N. N., Koptil' V. I. Poligenez almazov v svyazi s problemoi korennykh rossypei severo-vostoka Sibirskoi platform [Polygenesis of diamonds in connection with the problem of bedrock placers in the north-east of the Siberian platform]. Doklady Akademii nauk-Reports of the Academy of Sciences, 1998, vol. 361, no. 3, pp. 366-369. (In Russ.)

5. Zinchuk N. N. Sravnitel'naya kharakteristika veshchestvennogo sostava kory vyvetrivaniya kimberlitovykh porod Sibirskoi i Vostochno-Evropeiskoi platform [Comparative characteristics of the material composition of the weathering crust of kimberlite rocks of the Siberian and East European platforms]. Geologiya i geofizika - Geology and geophysics, 1992, no. 7, pp. 99-109. (In Russ.)

6. Afanas'ev V. P., Zinchuk N. N., Tychkov S. A. Problema almazonosnosti Sibirskoi platformy [The problem of diamond content of the Siberian platform]. Vestnik Voronezhskogo gosudarstvennogo universiteta. Seriya: Geologiya - Proceedings of Voronezh State University. Series: Geology, 2002, no. 1, pp. 19-36. (In Russ.)

7. Savko A. D., Zinchuk N. N., Shevyrev L. T., Il'yash V. V., Afanas'ev N. S. Almazonosnost' Voronezhskoi anteklizy [Diamond content of the Voronezh anteclise]. Trudy Nauchno-issledovatel'skogo Instituta Geologii [The work of the Research Institute of Geology], Voronezh, VSU Publ., 2003, vol.17, 121 p. (In Russ.) 8. Afanas'ev V. P., Zinchuk N. N. Osnovnye litodinamicheskie tipy oreolov indikatornykh mineralov kimberlitov i obstanovki ikh formirovaniya [Basic lithodynamic types of halos of indicator minerals of kimberlites and conditions of their formation]. Geologiya rudnykh mestorozhdenii - Geology of ore deposits, 1999, vol. 41, no. 3, pp. 281-288. (In Russ.)

9. Zinchuk N. N., Koptil' V. I., Boris E. I., Lipashova A. N. Tipomorfizm almazov iz rossypei Sibirskoi platformy kak osnova poiskov almaznykh mestorozhdenii [Typomorphism of diamonds from placers of the Siberian platform as a basis for prospecting for diamond deposits]. Rudy i metally - Ores and metals, 1999, no. 3, pp. 18-30. (In Russ.)

10. Zinchuk N. N., Savko A. D., Koptil' V. I., Chashka A. I., Polkanov Yu. A., Palkina E. Yu., Khrenov A. Ya., Shevyrev L. T. Sravnitel'naya kharakteristika tipomorfnykh osobennostei almazov iz terrigennykh otlozhenii Voronezhskoi anteklizy (Lipetskaya oblast') i Ukrainskogo shchita (Srednee Pridnestrov'e) v svyazi s problemoi prognozirovaniya i poiskov ikh korennykh istochnikov [Comparative characteristic of typomorphic features of diamonds from terrigenous deposits of the Voronezh anteclise (Lipetsk region) and the Ukrainian shield (Middle Transnistria) in connection with the problem of forecasting and searching for their primary sources]. Vestnik Voronezhskogo gosudarstvennogo universiteta. Seriya: Geologiya - Proceedings of Voronezh State University. Series: Geology, 2004, no. 2, pp. 99-110. (In Russ.)

11. Mal'tsev M. V., Tolstov A. V., Fomin V. M., Starkova T. S. Novoe limberlitovoe pole v Yakutii i tipomorfnye osobennosti ego mineralov-indikatorov [New limberlite field in Yakutia and typomorphic features of its indicator minerals]. Vestnik Voronezhskogo gosudarstvennogo universiteta. Seriya: Geologiya - Proceedings of Voronezh State University. Series: Geology, 2016, no. 3, pp. 86-94. (In Russ.) 12. Vasilenko V. B., Zinchuk N. N., Kuznetsova L. G. Geodinamicheskii kontrol' razmeshcheniya kimberlitovykh polei tsentral'noi i severnoi chastei Yakutskoi kimberlitovoi provintsii (petrokhimicheskii aspekt) [Geodynamic control of the location of kimberlite fields in the central and northern parts of the Yakutsk kimberlite province (petrochemical aspect)]. Vestnik Voronezhskogo gosudarstvennogo universiteta. Seriya: Geologiya - Proceedings of Voronezh State University. Series: Geology, 2000, no.3.(9), pp. 37-55. (In Russ.)

13. Metelkina M. P., Prokopchuk B. I., Sukhodol'skaya O. V., Frantsesson E. V. Dokembriiskie almazonosnye formatsii Mira [Precambrian diamondiferous formations of the World.]. Moscow, Nedra publ., 1976, 134 p. (In Russ.)

14. Zinchuk N. N., Boris E. I., Yanygin Yu. B. Osobennosti mineragenii almaza $v$ drevnikh osadochnykh tolshchakh (na primere verkhnepaleozoiskikh otlozhenii Sibirskoi platformy) [Peculiarities of diamond minerageny in ancient sedimentary strata (on the example of the Upper Paleozoic deposits of the Siberian platform)]. Moscow, MGT publ., 2004, 172 p. (In Russ.)

15. Orlov Yu. L. Mineralogiya almaza. 2-e izd [Mineralogy of diamond. 2nd ed.]. Moscow, Nauka publ., 1984, 264 p. (In Russ.)

16. Afanas'ev V. P., Pokhilenko N. P., Logvinova A. M., Zinchuk N. N., Efimova E. S., Saf'yannikov V. I., Krasavchikov V. O., Podgornykh M. M., Prugov V. P. Osobennosti morfologii i sostava nekotorykh khromshpinelidov almazonosnykh ploshchadei v svyazi s problemoi «lozhnykh» indikatorov kimberlitov [Peculiarities of morphology and composition of some Cr-spinels of diamondiferous areas in connection with the problem of "false" indicators of kimberlites]. Geologiya i geofizika - Geology and geophysics, 2000, vol. 41, no. 12, pp. 1729-1741. (In Russ.)

17. Zinchuk N. N., Mel'nik Yu. M., Serenko V. P. Apokimberlitovye porody [Apokimberlite rocks]. Geologiya i geofizika - Geology and geophysics, 1987, no. 10, pp. 66-72. (In Russ.)

18. Zinchuk N. N., Zuev V. M., Koptil' V. I., Chernyi S. D. Strategiya vedeniya i rezul'taty almazopoiskovykh rabot [Strategy of conducting and results of diamond prospecting operations]. Gornyi vestnik Mining Bulletin, 1997, no. 3, pp. 53-57. (In Russ.)

19. Afanas'ev V. P., Zinchuk N. N., Logvinova A. N. Osobennosti raspredeleniya rossypnykh almazov, svyazannykh s dokembriiskimi istochnikami [Peculiarities of distribution of placer diamonds associated with Precambrian sources]. Zapiski Rossiiskogo mineralogicheskogo obshchestva - Notes of the Russian Mineralogical Society, 2009, vol. 138, no. 2, pp. 1-13. (In Russ.)

20. Grachanov S. A., Zinchuk N. N., Sobolev N. V. The age of Predictable primary diamond sources in the Northeastern Sibirian platform. Doklady Earth Sciences, 2015, vol. 465, no. 2, pp. 1297-1301.
Зинчук Николай Николаевич - д. г.-м. н., профессор, академик Академии наук РС (Якутия), председатель ЗЯНЦ АН PC (Я), Мирный, Республика Саха (Якутия), Российская Федерация; E-mail: nnzinchuk@ rambler.ru, ORCID http://orcid.org/0000-0002-9682-3022

Автор прочитал и одобрил окончательный вариант рукописи.
Nikolai N. Zinchuk - PhD, Dr. habil. in Geol.-Min., professor, academician of the Academy of Sciences of the RS (Yakutia), chairman of West-Yakutian Scientific Centre of the SR (Yakutia) Academy of Sciences, Mirny, Republic of Sakha (Yakutia), Russian Federation; E-mail: nnzinchuk@ rambler.ru, ORCID http://orcid.org/0000-0002-9682-3022 Author have read and approved the final manuscript. 